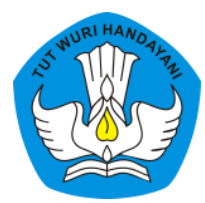

Page: 547-566

\title{
PENGARUH MODEL SNOWBALL THROWING DAN MINAT TERHADAP HASIL BELAJAR ILMU PENGETAHUAN SOSIAL SEKOLAH DASAR
}

\author{
Ali Masria \\ Sekolah Dasar Negeri 02 Lembah Melintan, Sumatera Barat, Indonesia \\ Contributor Email: alimuhammad7079@gmail.com
}

Received: Feb 16, 2021

Accepted: Jun 16, 2021

Published: Jul 30, 2021

Article Url: https://ojsdikdas.kemdikbud.go.id/index.php/didaktika/article/view/377

\begin{abstract}
The purpose of this study was to see the difference in the influence of the Snowball Throwing model, conventional models and students' interest in learning on learning outcomes. This type of research is a quasi-experimental research using a quantitative approach. The population was all fourth grade students of the Gugus III Public Elementary School, Lembah Melintang District, while the sample consisted of 42 grade IV students at the 02 Lembah Melintang Elementary School. 21 students in the experimental class and 21 students in the control class. Data from research results obtained from student learning outcomes tests. The ratio of $X_{1}$ and $X_{2}$ to $Y$ is $16.25 \%$, while the percentage ratio of $X_{2}$ and $X_{2} b$ to $Y$ is $16.82 \%$. The results show that there is an influence of the Snowball Throwing model and interest in learning outcomes of Social Sciences in class IV Elementary School 02 Lembah Melintang.
\end{abstract}

Keywords: Snowball Throwing Model; Interest; Social Science Outcomes. 


\begin{abstract}
Abstrak
Penelitian ini melihat perbedaan pengaruh model Snowball Throwing, model konvensional, dan minat belajar siswa terhadap hasil belajar. Jenis penelitian ini adalah penelitian eksperimen semu menggunakan pendekatan kuantitatif. Populasi siswa kelas IV Sekolah Dasar Negeri Gugus III Kecamatan Lembah Melintang, sampelnya adalah siswa kelas IV Sekolah Dasar Negeri 02 Lembah Melintang sebanyak 42 orang. Sebanyak 21 orang siswa pada kelas eksperimen dan 21 orang siswa pada kelas kontrol. Data dari hasil penelitian diperoleh dari tes hasil belajar siswa. Perbandingan $\mathrm{X}_{1}$ dan $\mathrm{X}_{2}$ terhadap $Y$ adalah $16,25 \%$, sedangkan persentase perbandingan $X_{2}$ a dan $X_{2}$ b terhadap $Y$ adalah 16,82\%. Hasil penelitian menunjukkan bahwa terdapat pengaruh model Snowball Throwing dan minat terhadap hasil belajar Ilmu Pengetahuan Sosial di kelas IV Sekolah Dasar Negeri 02 Lembah Melintang.
\end{abstract}

Kata Kunci: $\quad$ Model Snowball Throwing; Minat; Hasil Belajar.

\title{
A. Pendahuluan
}

Model pembelajaran Snowball Throwing cocok digunakan dalam pembelajaran Ilmu Pengetahuan Sosial. Pembelajaran Ilmu Pengetahuan Sosial harus disajikan secara interaktif, artinya pembelajaran yang dapat membangkitkan minat, perhatian siswa, serta minat siswa dalam belajar. Oleh karena itu, seorang guru harus mampu menyusun dan melaksanakan model pembelajaran yang mampu menjadikan siswa aktif, inovatif, kreatif, efektif, dan menyenangkan sehingga terwujud pembelajaran aktif, inovatif, kreatif, efektif, dan menyenangkan yang dapat meningkatkan minat siswa dalam pembelajaran.

Berdasarkan observasi yang penulis lakukan di Sekolah Dasar Negeri Gugus III Lembah Melintang, ditemukan beberapa permasalahan pembelajaran Ilmu Pengetahuan Sosial di antaranya guru lebih cenderung menggunakan metode konvensional seperti metode ceramah, metode tanya jawab, dan metode penugasan. Selain itu, guru belum mampu menumbuhkan suasana belajar yang menyenangkan, menarik, menantang, merangsang serta melibatkan siswa secara aktif. Hal ini membuat siswa tidak semangat sehingga siswa kurang berminat dalam mengikuti pembelajaran dan berdampak terhadap hasil belajar siswa dalam belajar Ilmu Pengetahuan Sosial berada di bawah kriteria ketuntasan minimal (KKM) yang ditetapkan yaitu 75". 
Ilmu Pengetahuan Sosial sangat penting diajarkan khususnya di Sekolah Dasar untuk mendidik siswa mengembangkan pengetahuan, sikap, dan keterampilan. Tujuannya agar siswa dapat mengambil bagian secara aktif dalam kehidupannya kelak sebagai anggota masyarakat dan warga negara yang baik. Ilmu Pengetahuan Sosial juga diberikan untuk bekal pengetahuan, bekal nilai dan sikap, serta keterampilan dalam kehidupan siswa di masyarakat, bangsa, dan negara. Hal ini sesuai dengan pendapat yang dikemukakan Gunawan (2011: 52) yang menjelaskan bahwa Ilmu Pengetahuan Sosial penting dengan tujuan untuk (a) membekali anak didik dengan pengetahuan sosial, (b) membekali anak didik dengan kemampuan mengidentifikasi, menganalisis dan menyusun alternatif pemecahan masalah sosial, (c) membekali anak didik dengan kemampuan berkomunikasi dengan sesama warga masyarakat, (d) membekali anak didik dengan kesadaran, sikap mental yang positif, dan keterampilan, dan (e) membekali anak didik dengan kemampuan mengembangkan pengetahuan dan keilmuan Ilmu Pengetahuan Sosial. Adapun tujuan pembelajaran Ilmu Pengetahuan Sosial yaitu agar siswa mampu mengembangkan pengetahuan, nilai, dan sikap serta keterampilan sosial yang berguna bagi dirinya, untuk mengembangkan pemahaman tentang pertumbuhan masyarakat Indonesia masa lampau hingga kini sehingga siswa bangga sebagai bangsa Indonesia. Hal inilah yang menyebabkan pembelajaran Ilmu Pengetahuan Sosial itu penting untuk dipelajari dan dipahami oleh siswa. Berdasarkan teori di atas perlu pembuktian dengan melakukan sebuah penelitian tentang pengaruh model Snowball Throwing dan minat terhadap hasil belajar Ilmu Pengetahuan Sosial khususnya di kelas IV Sekolah Dasar Negeri 02 Lembah Melintang.

Handayani, dkk (2017) menyatakan bahwa Snowball Throwing merupakan pembelajaran yang dilakukan berupa sebuah permainan dengan melempar bola pertanyaan dari kertas yang diremas seperti bola salju. Peserta didik yang mendapat satu bola, membaca pertanyaan di depan kelas dan memberikan jawabannya. Model pembelajaran ini melatih siswa untuk lebih tanggap menerima pesan dari siswa lain dalam bentuk 
bola salju yang terbuat dari kertas dan menyampaikan pesan tersebut kepada temannya dalam satu kelompok.

Andi (2016) menyatakan bahwa model pembelajaran Snowball Throwing yang menggali potensi kepemimpinan siswa dalam kelompok dan keterampilan membuat dan menjawab pertanyaan yang dipadukan melalui suatu permainan imajinatif membentuk dan melempar bola salju.

Febriany (2019) juga menyatakan bahwa model Snowball Throwing merupakan salah satu tipe dari model pembelajaran kooperatif yang dikembangkan berdasarkan pendekatan kontekstual. Snowball Throwing yang menurut asal kata berarti "bola salju bergulir", dapat diartikan sebagai model pembelajaran dengan menggunakan bola pertanyaan dari kertas yang digulung bulat berbentuk bola kemudian dilemparkan secara bergiliran di antara sesame anggota kelompok.

Kurniasih (2015: 77) menjelaskan snowball throwing merupakan model pembelajaran dengan menggunakan bola pertanyaan dari kertas yang digulung bulat berbentuk bola, kemudian dilempar secara bergantian antara sesama kelompok. Model pembelajaran Snowball Throwing merupakan salah satu model pembelajaran efektif, efisien, dan inovatif karena siswa dituntut untuk berpikir kritis dan aktif dalam suatu pembelajaran. Model pembelajaran ini sangat sesuai untuk dilaksanakan bagi siswa yang memiliki pemahaman rendah serta daya pikir yang kurang. Selain itu, model ini juga dapat diterapkan bagi siswa yang sebenarnya pintar hanya saja mereka tidak mampu untuk mengungkapkan pendapatnya. Caranya, bila ada pertanyaan yang sama maka siswa harus tetap menjawabnya di depan kelas (Lestari, 2015).

Berdasarkan pendapat ahli di atas dapat dimaknai bahwa model pembelajaran Snowball Throwing adalah model pembelajaran kelompok, masing-masing kelompok diwakili oleh ketua kelompok untuk mendapatkan tugas dari guru untuk menyampaikan kembali materi yang sudah dijelaskan guru kepada anggota kelompok lainnya. Masing-masing anggota kelompok ditugaskan untuk membuat pertanyaan yang dituliskan dalam kertas. Kertas tersebut kemudian dibuat seperti bola dan dilempar ke siswa lain. Masing- masing siswa menjawab pertanyaan dari bola yang diperolehnya. 
Tingkah laku yang muncul saat mengikuti proses pembelajaran mengindikasikan akan ketertarikan dan ketidaktertarikan siswa terhadap pelajaran. Ketertarikan siswa ini merupakan salah satu tanda minat. Minat merupakan suatu kesukaan, kegemaran, atau kesenangan akan sesuatu. Uraian di atas senada dengan Susanto (2013:58) yang menyatakan minat sebagai dorongan dalam diri seseorang atau faktor yang menimbulkan ketertarikan atau perhatian secara efektif, yang menyebabkan dipilihnya suatu objek atau kegiatan menguntungkan, menyenangkan, dan akhirnya akan mendatangkan kepuasan tersendiri. Sedangkan Sefrina (2013: 28) menjelaskan bahwa minat merupakan sebuah ketertarikan pada suatu objek yang berasaal dari hati, bukan karena paksaan dari orang lain. Slameto (2010: 180) menyatakan minat adalah sesuatu rasa lebih suka dan rasa ketertarikan pada suatu hal atau aktivitas, tanpa ada yang menyuruh.

Ketekunan siswa dalam mengikuti pembelajaran akan terpacu dengan adanya minat siswa dalam belajar. Hal ini senada dengan yang dinyatakan Noor (2015) fungsi minat belajar yaitu (a) Sebagai kekuatan yang mendorong siswa untuk belajar, (b) Pendorong siswa untuk berbuat dalam mencapai tujuan, (c) Penentu arah perbuatan siswa yakni ke arah tujuan yang hendak dicapai, (d) Penyeleksi perbuatan sehingga perbuatan siswa yang mempunyai minat senantiasa selektif dan tetap terarah kepada tujuan yang ingin dicapai.

Khairani (2014:147) menyatakan fungsi minat dalam belajar mencakup (a) minat memudahkan terciptanya konsentrasi, (b) minat mencegah gangguan perhatian di luar, (c) minat memperuat melekatnya bahan pelajaran dalam ingatan, dan (d) minat memperkecil kebosanan dalam diri siswa".

Berdasarkan pendapat para ahli di atas, dapat dimaknai bahwa minat mampu mendorong semangat belajar siswa, mampu mengalihkan perhatian terhadap hal lain yang mengganggu pembelajaran, mampu memperkuat ingatan terhadap materi yang dipelajari, mampu mengurangi kebosanan dan meningkatkan konsentrasi dalam pembelajaran.

Indikator minat diperlukan untuk mengukur seberapa besar minat siswa ketika mengikuti proses pembelajaran. Lestari dan Mohammad (2015: 
83) menyatakan indikator untuk mengukur minat belajar di antaranya (a) senang, (b) tertarik, (c) perhatian, dan (d) aktif. Ini sejalan dengan Slameto (2010: 180) yang menyatakan bahwa minat merupakan rasa lebih suka dan rasa ketertarikan pada suatu aktivitas, tanpa ada yang menyuruh. Suatu minat dapat diekspresikan melalui suatu pernyataan yang menunjukkan bahwa siswa lebih menyukai suatu hal daripada hal lainnya, dapat pula dimanifestasikan melalui partisipasi dalam suatu aktivitas. Siswa yang memiliki minat terhadap subjek tertentu cenderung untuk memberikan perhatian yang lebih besar terhadap subjek tertentu.

Berdasarkan pendapat di atas dalam penelitian ini dirumuskan indikator untuk mengukur minat belajar siswa mencakup (a) rasa senang, (b) rasa ketertarikan untuk belajar, (c) perhatian saat belajar, dan (d) keaktifan dalam belajar.

Tujuan dari penelitian ini adalah untuk membuktikan pengaruh model Snowball Throwing dan minat terhadap hasil belajar siswa dalam pembelajaran Ilmu Pengetahuan Sosial di kelas IV Sekolah Dasar.

Berdasarkan uraian di atas, rumusan masalah penelitian ini adalah (1) Apakah hasil belajar siswa dengan model Snowball Throwing, lebih tinggi dari hasil belajar siswa model konvensional?; (2) Apakah hasil belajar siswa dengan model Snowball Throwing minat tinggi, lebih tinggi dari hasil belajar siswa dengan model Konvensional minat tinggi?; (3) Apakah hasil belajar siswa dengan model Snowball Throwing minat rendah, lebih tinggi dibandingkan hasil belajar siswa dengan model konvensional minat rendah?; dan (4) Apakah terdapat interaksi antara model Snowball Throwing dan minat terhadap hasil belajar siswa?

\section{B. Metode}

Jenis penelitian yang digunakan dalam penelitian ini adalah penelitian eksperimen semu menggunakan pendekatan kuantitatif. Tujuan penelitian ini adalah untuk membuktikan pengaruh model Snowball Throwing dan minat terhadap hasil belajar Ilmu Pengetahuan Sosial. Penelitian ini dilaksanakan di SDN 02 Lembah Melintang pada semester genap tahun ajaran 2020/2021. 
Sampel penelitian ini adalah seluruh peserta didik Kelas IV Sekolah Dasar Negeri 02 Lembah Melintang yang berjumlah 42 orang.

Prosedur yang sistematis dapat digunakan untuk mencapai tujuan penelitian. Secara umum, prosedur penelitian dibagi menjadi tiga tahap yaitu tahap persiapan, tahap pelaksanaan, dan tahap penilaian. Pada tahap persiapan ini peneliti mempersiapkan segala sesuatu yang berhubungan dengan pelaksanaan peneliti yaitu (1) menetapkan jadwal penelitian, (2) menentukan kelas sampel yaitu kelas eksperimen dan kelas kontrol, (3) mempersiapkan silabus dan Rencana Pelaksanaan Pembelajaran (RPP), (4) mempersiapkan instrumen penelitian berupa tes (kisi-kisi, soal uji coba, dan kunci jawaban soal uji coba tes), (5) mempersiapkan sumber-sumber, alat-alat dan bahan-bahan yang diperlukan untuk mendukung pembelajaran model Snowball Throwing, dan (6) mempersiapkan angket minat siswa. Pada tahap pelaksanaan, peneliti melakukan pembelajaran di kelas eksperimen dengan menggunakan model Snowball Throwing, sedangkan di kelas kontrol menggunakan pembelajaran konvensional.

Instrumen yang digunakan pada penelitian ini ada dua intrumen yaitu angket tentang minat siswa dan tes hasil belajar. Angket digunakan untuk mendapatkan data minat belajar siswa, dengan cara menyebarkan lembaran angket tentang minat belajar siswa. Angket ini bertujuan untuk mengetahui informasi secara lengkap tentang minat siswa terhadap pembelajaran yang telah dilaksanakan. Variabel minat belajar dibuat instrumen berupa angket yang diberikan kepada siswa dengan menggunakan skala Likert. Angket ini digunakan untuk melihat minat siswa. Angket ini dirancang dengan menggunakan jawaban yaitu Selalu (SL), Sering (SR), Kadang-kadang (KD), Jarang (JR), dan Tidak Pernah (TP). Masing-masing mempunyai skor dari 5, 4, 3, 2, dan 1 untuk pernyataan positif atau 1, 2, 3, 4 dan 5 untuk pernyataan negatif. 
Tabel 1. Lembar Angket Minat Belajar Ilmu Pengetahuan Sosial Siswa Kelas IV SD

\begin{tabular}{|c|c|c|c|c|c|c|}
\hline No & Pernyataan & L & $\mathbf{R}$ & D & $\mathbf{R}$ & $\mathbf{P}$ \\
\hline A & Adanya perasaan senang dalam aktivitas belajar & & & & & \\
\hline 1 & $\begin{array}{l}\text { Saya merasa senang setiap kali belajar mata } \\
\text { pelajaran Ilmu Pengetahuan Sosial }\end{array}$ & & & & & \\
\hline 2 & Saya mengeluh kepada guru jika diberikan tugas & & & & & \\
\hline 3 & $\begin{array}{l}\text { Saya senang membaca buku yang berhubungan } \\
\text { dengan mata pelajaran Ilmu Pengetahuan Sosial }\end{array}$ & & & & & \\
\hline 4 & $\begin{array}{l}\text { Pekerjaan rumah yang diberikan guru, saya kerjakan } \\
\text { dengan senang hati tanpa menunda-nunda waktu }\end{array}$ & & & & & \\
\hline 5 & $\begin{array}{l}\text { Saya mengikuti setiap proses pembelajaran Ilmu } \\
\text { Pengetahuan Sosial dengan tekun }\end{array}$ & & & & & \\
\hline 6 & $\begin{array}{l}\text { Saya merasa bosan saat belajar mata pelajaran } \\
\text { Ilmu Pengetahuan Sosial }\end{array}$ & & & & & \\
\hline 7 & $\begin{array}{l}\text { Saya masuk kelas lebih dulu dari guru, saat } \\
\text { belajar mata pelajaran Ilmu Pengetahuan Sosial }\end{array}$ & & & & & \\
\hline B & Ketertarikan untuk belajar & & & & & \\
\hline 8 & $\begin{array}{l}\text { Saya selalu semangat belajar Ilmu Pengetahuan } \\
\text { Sosial agar mendapat pujian dari guru }\end{array}$ & & & & & \\
\hline 9 & $\begin{array}{l}\text { Saya membeli buku paket Ilmu Pengetahuan } \\
\text { Sosial karena ingin memahami materi pelajaran } \\
\text { Ilmu Pengetahuan Sosial }\end{array}$ & & & & & \\
\hline 10 & $\begin{array}{l}\text { Saya mengulang kembali pelajaran Ilmu Pengetahuan } \\
\text { Sosial dirumah karena disuruh ibu }\end{array}$ & & & & & \\
\hline 11 & $\begin{array}{l}\text { Saya selalu mengerjakan soal-soal latihan pada } \\
\text { buku Paket Ilmu Pengetahuan Sosial karena kemauan } \\
\text { sendiri }\end{array}$ & & & & & \\
\hline 12 & $\begin{array}{l}\text { Saya merasa ketinggalan pelajaran Ilmu Pengetahuan } \\
\text { Sosial apabila tidak masuk kelas }\end{array}$ & & & & & \\
\hline $\mathrm{C}$ & Keterlibatan dalam pembelajaran & & & & & \\
\hline 13 & $\begin{array}{l}\text { Saya bertanya kepada guru jika ada materi } \\
\text { pelajaran Ilmu Pengetahuan Sosial yang kurang } \\
\text { saya mengerti }\end{array}$ & & & & & \\
\hline 14 & $\begin{array}{l}\text { Saya aktif berpendapat dalam pembelajaran } \\
\text { kerana ingin dipuji }\end{array}$ & & & & & \\
\hline 15 & $\begin{array}{l}\text { Saya mengajarkan teman yang kurang pandai } \\
\text { agar mendapatkan pujian dari guru }\end{array}$ & & & & & \\
\hline 16 & Saya menanggapi pendapat teman dalam diskusi & & & & & \\
\hline 17 & $\begin{array}{l}\text { Saya ikut mengerjakan tugas kelompok yang } \\
\text { diberikan oleh guru bersama teman sekelompok }\end{array}$ & & & & & \\
\hline 18 & $\begin{array}{l}\text { Saya hanya duduk diam di kelas, saat diskusi } \\
\text { kelas berlansung }\end{array}$ & & & & & \\
\hline D & Memberikan perhatian yang besar dalam belajar & & & & & \\
\hline 19 & $\begin{array}{l}\text { Saya memperhatikan setiap materi pelajaran Ilmu } \\
\text { Pengetahuan Sosial yang disampaikan guru karena } \\
\text { ingin memahami setiap materi Ilmu Pengetahuan } \\
\text { Sosial }\end{array}$ & & & & & \\
\hline
\end{tabular}




\begin{tabular}{|c|l|l|l|l|l|l|}
\hline No & \multicolumn{1}{|c|}{ Pernyataan } & L & R & D & R & P \\
\hline 20 & $\begin{array}{l}\text { Saya mengobrol dengan teman lain saat guru } \\
\text { menerangkan materi Ilmu Pengetahuan Sosial }\end{array}$ & & & & & \\
\hline 21 & $\begin{array}{l}\text { Saya keluar masuk kelas ketika guru menerangkan } \\
\text { materi pelajaran Ilmu Pengetahuan Sosial }\end{array}$ & & & & \\
\hline 22 & $\begin{array}{l}\text { Saya melamun saat guru menerangkan materi } \\
\text { pelajaran Ilmu Pengetahuan Sosial }\end{array}$ & & & & \\
\hline
\end{tabular}

\section{Hasil dan Pembahasan}

\section{Hasil}

Hasil penelitian ini ditunjukkan pada pengujian hipotesis 1 sampai

4. Berikut disajikan data pengujian hipotesis 1 sampai 4.

1.1. Uji Hipotesis 1

Hasil perhitungan uji t untuk hipotesis 1 terlihat pada tabel berikut.

Tabel 2. Hasil Uji t Hipotesis 1

\begin{tabular}{|l|c|c|c|c|}
\hline \multicolumn{1}{|c|}{ Kelas } & N & Rata-rata & Df & Sig. \\
\hline Eksperimen & 20 & 85,90 & \multirow{2}{*}{38} & \multirow{2}{*}{0,000} \\
\hline Kontrol & 20 & 69,65 & & \\
\hline
\end{tabular}

Berdasarkan tabel di atas, diperoleh nilai sig. lebih kecil dari tarafnya 0,05, maka hipotesis nol ditolak. Artinya, terdapat perbedaan rata-rata yang signifikan antara hasil belajar siswa yang menggunakan model Snowball Throwing dari siswa yang menggunakan metode konvensional. Ini dikarenakan rata-rata hasil belajar siswa yang menggunakan model Snowball Throwing lebih tinggi dari siswa yang menggunakan metode konvensional. Berdasarkan data di atas, berarti penggunaan model Snowball Throwing dalam pembelajaran Ilmu Pengetahuan Sosial mampu meningkatkan hasil belajar siswa dari pada penggunaan model konvensional.

\subsection{Uji Hipotesis 2}

Tabel 3. Hasil Uji t Hipotesis 2

\begin{tabular}{|l|c|c|c|c|}
\hline \multicolumn{1}{|c|}{ Minat Tinggi } & N & Rata-rata & Df & Sig. \\
\hline Eksperimen & 12 & 89,83 & \multirow{2}{*}{19} & \multirow{2}{*}{0,000} \\
\hline Kontrol & 9 & 77,56 & & \\
\hline
\end{tabular}

Berdasarkan tabel di atas, diperoleh nilai sig. lebih kecil dari tarafnya 0,05, maka hipotesis nol ditolak. Artinya terdapat perbedaan rata-rata yang 
signifikan antara hasil belajar siswa yang memiliki minat belajar tinggi yang belajar dengan model Snowball Throwing dari pada hasil belajar siswa yang memiliki minat belajar tinggi yang belajar dengan model konvensional. Hal ini membuktikan bahwa penggunaan model Snowball Throwing mampu meningkatkan hasil belajar siswa yang berminat tinggi dari pada penggunaan model konvensional. Perbedaan itu terlihat sangat signifikan.

\subsection{Uji Hipotesis 3}

Tabel 4. Hasil Uji t Hipotesis 3

\begin{tabular}{|l|c|c|c|c|}
\hline \multicolumn{1}{|c|}{ Minat Rendah } & N & Rata-rata & Df & Sig. \\
\hline Eksperimen & 8 & 80,00 & \multirow{2}{*}{17} & 0,03 \\
\hline Kontrol & 11 & 63,18 & & \\
\hline
\end{tabular}

Berdasarkan tabel di atas, diperoleh nilai sig. lebih kecil dari tarafnya 0,05, maka hipotesis nol ditolak. Artinya, terdapat perbedaan rata-rata yang signifikan antara hasil belajar siswa yang memiliki minat rendah yang mengikuti pembelajaran menggunakan model Snowball Throwing dari siswa yang memiliki minat rendah belajar menggunakan metode konvensional. Data di atas juga membuktikan bahwa penggunaan model Snowball Throwing mampu meningkatkan hasil belajar siswa yang memiliki minat belajar rendah dari pada penggunaan model konvensional.

\subsection{Uji Hipotesis 4}

\section{Tabel 5. Hasil Uji Anava 2 arah Hipotesis 4}

Tests of Between-Subjects Effects

Dependent variable: Hasil

\begin{tabular}{|l|c|c|c|c|c|}
\hline \multicolumn{1}{|c|}{ Source } & Type III Sum of Squares & df & Mean Square & F & Sig. \\
\hline Corrected Model & $4125.110^{\mathrm{a}}$ & 3 & 1375.037 & 159.672 & .000 \\
Intercept & 234962.248 & 1 & 234962.248 & 27284.30 & .000 \\
Minat & 1420.466 & 1 & 1420.466 & 164.947 & .000 \\
Model & 2069.503 & 1 & 2069.503 & 240.315 & .000 \\
Minat * Model & 49.344 & 1 & 49.344 & 5.730 & .022 \\
Error & 310.019 & 36 & 8.612 & & \\
Total & 246306.053 & 40 & & & \\
Corrected Total & 4435.129 & 39 & & & \\
\hline
\end{tabular}

a. R Squared $=.930$ (Adjusted R Squared $=.924)$ 
Berdasarkan tabel di atas, diperoleh nilai sig. kurang dari tarafnya 0,05, maka hipotesis nol ditolak. Artinya terdapat interaksi yang signifikan antara model Snowball Throwing dan minat dalam memengaruhi hasil belajar siswa.

Model Snowball Throwing dan minat memengaruhi hasil belajar karena (a) model Snowball Throwing mampu meningkatkan keaktifan siswa dalam belajar; (b) minat memiliki peran yang penting dalam menunjang keberhasilan belajar; (c) model Snowball Throwing menjadikan siswa berminat dalam belajar. Hal ini sejalan dengan pendapat Hamdayana (2014) yang menyatakan bahwa model Snowball Throwing membuat suasana pembelajaran menjadi menyenangkan serta melibatkan siswa menjadi aktif dalam pembelajaran. Ini juga sejalan dengan fungsi minat yang dinyatakan Noor (2015) bahwa minat sebagai kekuatan yang mendorong siswa untuk belajar sehingga siswa mampu mencapai hasil belajar yang baik.

\section{Pembahasan}

Setelah dilakukan analisis data dengan menggunakan uji-t pada hipotesis 1, 2, dan 3 serta uji ANAVA dua jalur terhadap hipotesis 4, temuan-temuan penelitian yang dilakukan di siswa kelas IV SDN 02 Lembah Melintang ini sesuai dengan temuan penelitian yang dikemukakan pada bagian terdahulu dari bab ini. Hal ini terjadi karena untuk memperoleh hasil belajar yang baik perlu model pembelajaran yang cocok terhadap mata pelajaran maupun materi yang akan disajikan. Pembahasan hasil penelitian disajikan pada bagian berikut ini.

\subsection{Hasil Belajar Siswa yang Belajar Menggunakan Model Snowball Throwing dan Model Konvensional}

Hasil pengujian hipotesis pertama menunjukkan bahwa secara keseluruhan, hasil belajar siswa yang belajar dengan menggunakan model Snowball Throwing lebih tinggi dari pada siswa yang belajar dengan model konvensional. Dari hasil temuan ini dapat dikemukakan bahwa model Snowball Throwing lebih efektif digunakan untuk meningkatkan hasil belajar 
Ilmu Pengetahuan Sosial. Temuan ini dapat dilihat dari hasil analisis statistik rerata hasil tes siswa yang diajar dengan model Snowball Throwing lebih tinggi dibandingkan dengan siswa yang diajarkan dengan pembelajaran konvensional.

Hasil perhitungan pengujian hipotesis pertama dengan menggunakan uji-t diperoleh nilai signifikan 0,000 lebih kecil dari taraf nyata 0,05. maka $\mathrm{H}_{\mathrm{o}}$ ditolak dan $\mathrm{H}_{1}$ diterima. Hal ini berarti belajar dengan menggunakan model Snowball Throwing memberikan pengaruh yang lebih baik dibandingkan dengan belajar menggunakan model konvensional. Hal ini sesuai penelitian yang dilakukan Sumarliani (2017) dalam uji hipotesisnya yang menunjukkan bahwa terdapat perbedaan yang signifikan hasil belajar Ilmu Pengetahuan Sosial antara siswa yang mendapat perlakuan dengan model Snowball Throwing bermediakan gambar dan siswa yang tidak mendapat perlakuan dengan model Snowball Throwing bermediakan gambar. Hasil uji hipotesis menunjukkan bahwa hasil belajar Ilmu Pengetahuan Sosial siswa dengan model pembelajaran Kooperatif Tipe Snowball Throwing bermediakan gambar lebih tinggi daripada yang tidak mendapat perlakuan. Hal ini berarti siswa yang diajar dengan model konvensional memiliki hasil belajar yang rendah.

Adnyana (2017) dalam penelitiannya juga membuktikan hipotesis bahwa hasil post-test Ilmu Pengetahuan Sosial kelompok eksperimen dengan model Snowball Throwing berbasis kearifan lokal memiliki hasil belajar lebih tinggi dibandingkan kelompok kontrol yang menggunakan model konvensional. Kusumayanti. (2013) menemukan bahwa pengaruh model Snowball Throwing berbantuan media konkret lebih unggul dibandingkan dengan metode ceramah untuk pencapaian hasil belajar Ilmu Pengetahuan Sosial Sekolah Dasar di gugus IV Kecamatan Buleleng. Keterkaitan antara hasil penelitian yang telah dilakukan sebelumnya dengan penelitian ini membuktikan bahwa model pembelajaran yang digunakan lebih penting walaupun menggunakan media yang berbeda tetapi tidak memengaruhi model Snowball Throwing untuk meningkatkan hasil belajar siswa.

Kasim (2015) menemukan bahwa dengan pembelajaran menggunakan model Snowball Throwing, hasil belajar siswa sudah memuaskan dan sudah 
sesuai dengan apa yang diharapkan dalam pembelajaran. Selain itu kemampuan guru dalam menggunakan model Snowbal Throwing pada pembelajaran Ilmu Pengetahuan Sosial dapat juga dibuktikan dengan penggunaan media pembelajaran yang sudah digunakan dengan baik atau dimanfaat dengan baik. Hasil penelitian ini sejalan dengan hasil penelitian yang telah dilakukan yakni hasil belajar siswa meningkat dengan menggunakan model pembelajaran Snowball Throwing walaupun menggunakan media pembelajaran yang berbeda.

Temuan hasil penelitian ini dapat dimaknai bahwa hasil belajar menggunakan model Snowball Throwing lebih baik dibanding model konvensional. Hal ini terjadi karena dalam kegiatan pembelajaran dengan model Snowball Throwing siswa dilatih untuk siap menerima materi yang disampaikan guru dengan serta adanya tanggung jawab menyampaikan materi tersebut kepada teman kelompoknya. Masing-masing anggota kelompok juga dilatih untuk saling berdiskusi tentang materi yang diperoleh serta saling berbagi dengan antar anggota kelompok.

Selain itu, kegiatan melempar bola pertanyaan dapat melatih siswa dalam menyelesaikan masalah dalam soal yang terdapat dalam bola kertas. Kelompok yang mendapatkan bola kertas yang berisi pertanyaan dari kelompok lain berdiskusi bersama anggota kelompok untuk menyelesaikannya. Selanjutnya, setelah menjawab soal-soal yang diperoleh, masing-masing anggota kelompok melaporkan jawabannya kepada semua siswa, dan siswa yang lain dilatih untuk memberikan tanggapan terhadap hasil jawaban temannya. Hal ini sesuai dengan yang dinyatakan oleh Kurniasih (2015: 78) dan Shoimi (2014: 175) bahwa model pembelajaran Snowball Throwing mampu melatih kesiapan siswa dan saling memberikan pengetahuan serta guru dapat melatih kesiapan siswa dalam menanggapi dan menyelesaikan masalah.

Dalam proses pembelajaran model konvensional guru berperan penuh. Siswa diposisikan sebagai objek belajar yang berperan sebagai penerima informasi secara pasif, belajar lebih banyak secara individual, teoritis, dan abstrak, pengetahuan dikonstruksikan oleh orang lain dan diperoleh melalui menghafal dan latihan-latihan. Hal ini membuat siswa yang memiliki 
minat rendah tidak tertarik untuk mengikuti pelajaran dengan baik dan tidak berusaha keras mengikuti pembelajaran karena memang tidak berminat dengan gaya pembelajaran konvensional tersebut.

Berdasarkan pemaparan di atas, hipotesis yang menyatakan bahwa terdapat perbedaan yang signifikan antara hasil belajar Ilmu Pengetahuan Sosial siswa yang mendapat perlakuan model Snowball Throwing dan siswa yang tidak mendapat perlakuan model pembelajaran Snowball Throwing di 02 Lembah Melintang, terbukti dalam penelitian ini.

\subsection{Hasil Belajar Siswa dengan Model Snowball Throwing Minat Tinggi} Lebih Tinggi dari Hasil Belajar Siswa dengan Model Konvensional Minat Tinggi

Hasil penelitian hipotesis kedua menunjukkan bahwa hasil belajar kelompok siswa yang memiliki minat tinggi yang belajar dengan model Snowball Throwing lebih tinggi dari siswa yang memiliki minat tinggi yang belajar dengan model konvensional. Hal ini diperkuat oleh hasil perhitungan pengujian hipotesis pertama dengan menggunakan uji-t diperoleh nilai signifikan 0,000 lebih kecil dari taraf nyata 0,05 . maka $\mathrm{H}_{\mathrm{o}}$ ditolak dan $\mathrm{H}_{1}$ diterima. Hal ini berarti belajar dengan menggunakan model Snowball Throwing memberikan pengaruh yang lebih baik dibandingkan dengan belajar menggunakan model konvensional dalam keadaan anak memiliki minat tinggi dalam belajar Ilmu Pengetahuan Sosial.

Hal ini karena model Snowball Throwing melatih siswa untuk mampu menguasai materi pelajaran yang diberikan. Hal ini dilakukan dengan cara memberikan kepercayaan kepada siswa dalam menyampaikan materi kepada temannya, mengajak siswa untuk melakukan permainan melempar bola kertas yang berisi pertanyaan. Permainan ini memicu keaktifan siswa sehingga mampu meningkatkan minatnya dalam belajar. Selain itu, siswa juga untuk menyampaikan hasil kerjanya ke depan kelas serta memberikan tanggapan terhadap penyampaian hasil kerja temannya. 
Ini berarti minat berfungsi untuk (a) memudahkan terciptanya konsentrasi, (b) mencegah gangguan perhatian di luar, (c) memperkuat melekatnya bahan pelajaran dalam ingatan, dan (d) memperkecil kebosanan dalam diri siswa. sehingga mampu meningkatkan hasil belajar. Hal ini sesuai dengan yang diungkapkan Khairani (2014: 147). Lain halnya dengan model konvensional yang tidak terdapat langkah pembelajaran yang mampu meningkatkan minat belajar siswa. Dengan demikian, terbukti hasil belajar siswa minat tinggi dengan model konvensional tidak lebih tinggi dari hasil belajar siswa minat tinggi dengan model Snowball Throwing.

\subsection{Hasil Belajar Siswa dengan Model Snowball Throwing Minat Rendah Lebih Tinggi dari Hasil Belajar Siswa dengan Model Konvensional Minat Rendah}

Hasil pengujian hipotesis ketiga menunjukkan secara umum kelompok siswa yang memiliki minat rendah di kelas eksperimen memperoleh hasil belajar yang lebih tinggi dari kelompok siswa yang memiliki minat rendah di kelas kontrol. Hal ini diperkuat oleh hasil perhitungan pengujian hipotesis kedua dengan menggunakan uji-t diperoleh nilai signifikan 0,03 lebih kecil dari taraf nyata 0,05 . maka $\mathrm{H}_{\mathrm{o}}$ ditolak dan $\mathrm{H}_{1}$ diterima. Hal ini berarti siswa yang memiliki minat rendah yang belajar dengan menggunakan model Snowball Throwing lebih baik dari siswa yang yang memiliki minat rendah yang belajar dengan model konvensional.

Hal ini terjadi karena pembelajaran dengan model Snowball Throwing meningkatkan minat siswa dalam pembelajaran. Siswa yang awalnya kurang berminat dalam pembelajaran Ilmu Pengetahuan Sosial, menjadi tertarik untuk mengikuti pembelajaran Ilmu Pengetahuan Sosial dengan maksimal. Dengan terangsangnya minat siswa yang belajar menggunakan model Snowball Throwing akan membuat siswa mulai semangat dalam mengikuti pembelajaran Ilmu Pengetahuan Sosial. Semangat yang telah muncul secara terus menerus cenderung menjadikan siswa berminat dalam belajar Ilmu Pengetahuan Sosial. 
Selanjutnya, model Snowball Throwing memberikan dampak positif kepada siswa di antaranya (1) meningkatkan jiwa kepemimpinan siswa, (2) melatih siswa belajar mandiri, (3) menumbuhkan kreativitas belajar siswa, (4) belajar lebih hidup, (5) suasana pembelajaran menjadi menyenangkan, (6) siswa mendapatkan kesempatan untuk mengembangkan kemampuan berpikir, (7) membuat siswa siap dengan berbagai kemungkinan, (8) siswa terlibat aktif dalam pembelajaran, (9) guru lebih efisien dalam membuat media, (10) pembelajaran menjadi lebih efektif, (7) aspek kognitif, afektif dan psikomotor dapat tercapai. Hal ini sesuai dengan yang dijelaskan Istarani (2014: 93) dan Hamdayana (2014).

\subsection{Interaksi antara Model Snowball Throwing dengan Minat Belajar} terhadap Hasil Belajar Ilmu Pengetahuan Sosial di Kelas V

Suatu interaksi terjadi manakala efek faktor yang satu tergantung pada faktor lain dalam mempengaruhui sesuatu. Ini berarti masing-masing faktor antara model Snowball Throwing dan minat belajar saling tergantung satu sama lainnya dalam memengaruhi hasil belajar. Hasil yang berkaitan dengan pengujian hipotesis interaksi, membuktikan bahwa terdapat interaksi antara Model Snowball Throwing dengan minat belajar terhadap hasil belajar. artinya hipotesis penelitian yang diajukan teruji kebenarannya secara signifikan. Hal ini diperkuat oleh hasil perhitungan pengujian hipotesis keempat dengan menggunakan uji ANAVA dua arah yaitu diperoleh nilai signifikan 0,02 lebih kecil dari taraf nyata 0,05. Ini berarti, $\mathrm{H}_{\mathrm{o}}$ ditolak dan $\mathrm{H}_{1}$ diterima. Hal ini berarti adanya interaksi antara model Snowball Throwing dengan minat dalam memengaruhi hasil belajar siswa dalam pembelajaran Ilmu Pengetahuan Sosial.

Berdasarkan temuan di atas, dapat disimpulkan bahwamodel Snowball Throwing mampu meningkatkan hasil belajar siswa. Siswa yang belajar dengan model Snowball Throwing memiliki hasil belajar yang lebih tinggi dibanding siswa yang belajar dengan model konvensional. Minat yang dimiliki siswa terhadap mata pelajaran juga mempunyai peran yang 
memengaruhi hasil belajar siswa. Siswa yang memiliki minat tinggi mendapatkan hasil belajar lebih tinggi dibandingkan dengan hasil belajar siswa yang memiliki minat rendah.

Interaksi antara model Snowball Throwing dan minat dalam memengaruhi hasil belajar terjadi karena tiga alasan berikut. Pertama, model Snowball Throwing mampu meningkatkan keaktifan siswa dalam belajar. Siswa yang aktif pertanda memiliki minat dalam belajar. Kedua, minat memiliki peran yang penting dalam menunjag keberhasilan belajar. Siswa yang memiliki minat tinggi memiliki hasil belajar yang tinggi dibanding siswa yang memiliki minat rendah, begitu juga dengan siswa yang belajar dengan model Snowball Throwing lebih baik dari siswa yang belajar dengan model konvensional. Ketiga, model Snowball Throwing dan minat sama-sama memengaruhi hasil belajar. Model Snowball Throwing menjadikan siswa berminat dalam belajar sehingga hasil belajar lebih baik, sedangkan siswa yang berminat akan memiliki hasil belajar yang baik juga. Berarti interaksi antara model Snowball Throwing dan minat akan membuat hasil belajar jadi lebih baik lagi.

Hal ini sesuai dengan pernyataan Hamdayana (2014) bahwa model Snowball Throwing membuat suasana pembelajaran menjadi menyenangkan serta melibatkan siswa menjadi aktif dalam pembelajaran. Senada dengan fungsi minat yang dinyatakan Noor (2015) bahwa minat sebagai kekuatan yang mendorong siswa untuk belajar sehingga siswa mampu mencapai hasil belajar yang baik.

Pembahasan di atas sesuai dengan teori belajar konstruktivisme yang membuat siswa aktif dalam kegiatan pembelajaran. siswa membina sendiri pengetahuannya, mencari arti dari apa yang mereka pelajari, serta menyelesaikan konsep dan ide-ide baru dengan kerangka berpikir yang telah ada dan dimilikinya. Pendekatan konstruktivisme mempunyai beberapa konsep umum antara lain sebagai berikut. (a) Siswa aktif membina pengetahuan berasaskan pengalaman yang sudah ada (b) Dalam konteks pembelajaran, siswa seharusnya membina sendiri pengetahuan mereka, (c) Pentingnya 
membina pengetahuan secara aktif oleh siswa sendiri melalui proses saling memengaruhi antara pembelajaran terdahulu dengan pembelajaran terbaru, (d) Unsur terpenting dalam teori ini ialah seseorang membina pengetahuan dirinya secara aktif dengan cara membandingkan informasi baru dengan pemahamannya yang sudah ada; (e) Ketidakseimbangan merupakan faktor motivasi pembelajaran yang utama. Faktor ini berlaku apabila seorang siswa menyadari gagasan-gagasannya tidak konsisten atau sesuai dengan pengetahuan ilmiah; dan (f) Bahan pengajaran yang disediakan perlu mempunyai perkaitan dengan pengalaman pelajar untuk menarik minat pelajar.

\section{Penutup}

Berdasarkan persentase data hasil belajar yang diperoleh, dapat disimpulkan bahwa model Snowball Throwing dan minat terbukti mampu memengaruhi hasil belajar siswa dalam pembelajaran Ilmu Pengetahuan Sosial di Kelas IV Sekolah Dasar Negeri 02 Lembah Melintang. Hal ini terlihat pada perbedaaan hasil belajar yang signifikan antara model Snowball Throwing dan model konvensional. Implikasi penelitian ini adalah dapat digunakan (1) sebagai pedoman bagi guru dan calon guru dalam membenahi dan mempersiapkan diri dalam proses pembelajaran, (2) sebagai bahan bagi kepala sekolah untuk memberikan bimbingan bagi guru dalam proses pembelajaran sehingga guru mampu meningkatkan keterampilan mengajar dengan model pembelajaran yang tepat, dan (3) sebagai bahan bagi pengawas sekolah terkait peningkatan kinerja guru dalam proses pembelajaran. Saran yang dapat dikemukakan di antaranya (1) guru kelas IV Sekolah Dasar Negeri 02 Lembah Melintang dapat menerapkan model pembelajaran Snowball Throwing dalam proses pembelajaran, karena terbukti dapat meningkatkan hasil belajar siswa, (2) peneliti selanjutnya dapat menerapkan model ini dalam pembelajaran pada mata pelajaran lain dengan level yang berbeda. Penelitian ini terbatas pada mata pelajaran Ilmu Pengetahuan Sosial semester 2, sehingga peneliti berikutnya dapat melaksanakannya pada semester 1 atau pada mata pelajaran lain, dan (3) lembaga terkait dapat mensosialisasikan 
tentang model Snowball Throwing untuk dapat benar-benar dilaksanakan dalam proses pembelajaran sesuai langkah-langkah yang tepat dan dapat menyediakan sarana dan prasarana yang dibutuhkan agar pembelajaran bermakna dan terlaksana dengan baik.

\section{Ucapan Terima Kasih}

Ucapan terima kasih saya sampaikan kepada Direktorat Pembinaan Guru Pendidikan Dasar, Dirjen Guru dan Tenaga Kependidikan, Kementerian Pendidikan dan Kebudayaan, Dinas Pendidikan Kabupaten Pasaman Barat, Kepala Sekolah, dan rekan-rekan guru di Sekolah Dasar Negeri 02 Lembah Melintang yang telah membantu dan memberikan kesempatan sehingga saya dapat menulis artikel ilmiah ini.

\section{Daftar Referensi}

Andi. (2016). Efektivitas Pembelajaran Matematika Melalui Penerapan Model Pembelajaran Kooperatif Tipe Snowball Throwing. Jurnal Tadris Matematika. Universitas Muhammadiyah Makasar. Vol. 9 No. 1 (Mei) 2016, Hal.61-74.

Aris, Shoimin. (2014). Model Pembelajaran Inovatif dalam Berkurikulum 2013. Yogyakarta : AR-RUZZ Media.

Dewi, Puspa. (2013). Pengaruh model pembelajaran Snowball Throwing Terhadap Hasil Belajar IPA Siswa Kelas IV SD di Gugus Sri Kandi Kecamatan Denpasar Timur. Jurnal PGSD FIP Universitas Pendidikan Ganesha. Volume 1 Number 2.

Hamdayana, Jumanta. (2014). Model dan Metode Pembelajaran Kreatif dan Berkarakter. Bogor: Ghalia Indonesia.

Handayani, N.S. (2017). Penerapan Model Pembelajaran Kooperatif Tipe Snowball Throwing terhadap Hasil Belajar Peserta Didik. Jurnal FKIP UNIPA Monokwari. Vol 2, No. 1 (2017).

Hayati, Tabrani ZA, Syahril, Saifullah Idris, Ramzi Murziqin. (2020). Construction of Islamic Education in the Education System in Emerging Perspectives and Trends in Innovative Technology for Quality Education 4.0. 1st Edition. London: Routledge 
Karim, Nany Febriany Abdul. (2019). Peningkatan Hasil Belajar IPA Melalui Model Pembelajaran Snowball Throwing Dengan Terapan Gerhana (Gerak Harmoni Bertanya) Pada Siswa Kelas VI SDN 57 kota Ternate. Jurnal Didaktika Pendidikan Dasar Kemdikbud. Vol. 3, No. 2, Oktober 2019.

Khairani, Makmun. (2013). Psikologi Belajar. Yogyakarta: Aswaja Pressindo.

Kurniasih, Imas., \& Berlin Sani. (2015). Ragam Pengembangan Model Pembelajaran untuk Peningkatan Profesionalitas Guru. Jogjakarta: Kata Pena.

Lestari, N., Hartono, Y., \& Purwoko.2016. “Pengaruh Pendekatan OpenEnded Terhadap Penalaran Matematika Siswa Sekolah Menengah Pertama Palembang". Jurnal Pendidikan Matematika .10 (1):82-97.

Pratiwy, Noor Komari (2015). Pengaruh Tingkat Pendidikan, Perhatian Orang Tua, dan Minat Belajar Siswa terhadap Prestasi Belajar Bahasa Indonesia Siswa SMK Kesehatan di Kota Tangerang. Jurnal Pujangga Volume 1, Nomor 2, Desember 2015.

Rudy, Gunawan. (2011). Pendidikan IPS: Filosofi, Konsep dan Aplikasi. Bandung: Alfabeta.

Saifullah Idris, Tabrani ZA, Fikri Sulaiman Ismail, \& Amsori. (2020). Assessment of critical education concepts in the perspective of Islamic education, in Emerging Perspectives and Trends in Innovative Technology for Quality Education 4.0. 1st Edition. London: Routledge

Sefrina, Andin. (2013). Deteksi Minat Bakat Anak. Yogyakarta: Buku Seru.

Slameto. (2010). Belajar dan Faktor yang memengaruhinya. Jakarta: Rineka Cipta.

Susanto, Ahmad. (2013). Teori Belajar \& Pembelajaran di Sekolah Dasar. Jakarta: Kencana.

Susanto, Ahmad. (2014). Pengembangan Pembelajaran IPS. Jakarta: Kencana. 